GLOBAL JOURNAL OF EDUCATIONAL RESEARCH VOL 11, NO. 2, 2012: 137-142

COPYRIGHT@ BACHUDO SCIENCE CO. LTD PRINTED IN NIGERIA. ISSN 1596-6224 www.globaljournalseries.com; Info@globaljournalseries.com

\title{
MOTIVATIONAL STRATEGIES AND POSSIBLE INFLUENCE ON SECONDARY SCHOOL TEACHERS' TEACHING PERFORMANCE
}

\author{
N. N. UKPONG AND C. C. UCHENDU
}

(Received 16 March 2012; Revision Accepted 30 May 2012)

\begin{abstract}
This study investigated the influence of motivational strategies on teachers' teaching performance in public secondary schools in Uyo - Urban, Akwa lbom State. One hypothesis was formed to guide the study and Expo Facto design was adopted for the study. A sample of three hundred and sixty (360) teachers were randomly selected from the population of all the secondary school teachers in the 18 public schools in the Area. A questionnaire based on four point likert-type scale was developed and administered to the 360 teachers. The data collected were subjected to statistical analyses using ANOVA. The test yielded significant influence of motivational strategies on teachers' work performance. Based on the findings, recommendations were made.
\end{abstract}

KEY WORDS: Motivational Strategies, Teaching Performance.

\section{INTRODUCTION}

The teacher is the one that would translate educational objectives specified in the National Policy on Education, into knowledge and skill and transfer them to students in the classroom. Also, the government may establish new schools, effect changes in the structure of the curriculum, recommend and prescribe teaching methods, but in the end, the teacher will be responsible for applying them to attain the goal of teaching and learning. Hence, Lash and Kirkpatrick (1990) pointed out that, the major responsibility of working with the school children rest with the teacher.

Obviously, despite the leading roles teachers play in the classroom towards attaining educational objectives, their motivation has remained a very serious problem in Nigeria. Ndu (1998) opines that teachers' motivation has been very low, that the situation of teachers in the school system was so bad that it had reached "an intolerable low point". As a result, the societal image of a teacher has made the "noble" profession unattractive as being inadequate for meeting economic, social and psychological needs. Under this condition, teachers' welfare needs are hardly considered by different stakeholders in Nigerian educational system. But, rather every parent want his children to acquire knowledge and skills, good morals and value without giving serious thought to how these would be transmitted without the teachers and more importantly, how teachers would perform without being motivated. The seriousness of the problem of lack of motivation for Nigerian teachers was supported by the result of a study of Ozigi (1992), who found out that teachers were unhappy, frustrated, uninspired and unmotivated. He then concluded that the nation's educational system was doomed. The concern of this paper is targeted at how teachers in our school system can be motivated to maximize high performance.

Motivations of teachers remain paramount in the school management process. Over the years, a number of researchers carried out studies which reveal how motivation can lead

N. N. Ukpong, Department of Educational Administration \& Planning, University Of Calabar, Calabar, Nigeria

C. C. Uchendu, Department of Educational Administration \& Planning, University Of Calabar, Calabar, Nigeria 
to maximum teaching performance in the school system. Ellis (1984) who carried out a study on "motivating teachers for excellence" concluded that teachers were primarily motivated within the school system by intrinsic rewards such as self respect, responsibility, and sense of accomplishment, praise and commendations. Therefore, school administrators can boost morale and motivate teachers to excel by means of participatory governance, in-service education and systematic supportive evaluation. A study by Ukpong (2003) concluded that motivation as a school management practice enables the administrator to inspire the employees to achieve their maximum potential productivity, by making it possible for them to achieve, and by assisting them to grow and be recognised. The study showed a significant influence of principals' level of motivation on teachers' attitude to work.

A study conducted by Pastor and Erlandson (1982) on "What motivate teachers" reveal that high internal motivation by school administrators, have shown that teachers were motivated more by intrinsic than extrinsic rewards. Their result revealed that teachers perceived their need and measured their job satisfaction by factors such as participation in decision-making, use of valued skills, freedom and independence, challenge of expression of creativity and opportunity for learning, which directly motivate them for greater performance. In a related study, Emanghe (1998) found that the use of interpersonal relationships by principals had a significant relationship with performance.

Amadi (1987), studied "Effects of Principals' leadership behaviour on teachers' level of commitment, conformity, cooperation and participation in school organization in Anambra State of Nigeria" and the result showed positive correlation between teachers' level of perception of their principals' leadership styles and their commitment to work. Bensimon (1989) conducted a study on "Making Sense of Administrative Leadership", and concluded that administrators who consider their role symbolic in perspective will be less concerned about displaying bold leadership in democratic administrative atmosphere. Therefore, democratic leadership of school principals would result in high teaching performance among teachers.

Other studies in support of positive relationship between leadership style of school principals and motivation of teachers for high teaching performance include Davis (1997), Bularch (1997), Martin (1990). They concluded that approximately one in three principals had leadership behaviours that create problems for them and their subordinates. That is, principals' behaviour that lack human consideration for motivation must certainly clash with teachers' interest and this slows down productivity. In addition, most of the mistakes school administrators make fall into the category of poor human relations and autocratic leadership-styles. The result of the studies ranked poor human relation as leadership tendencies which demand teachers' effectiveness in school work. Martin (1990) opines that unsuccessfulness in principalship is traceable to failure to motivate staff and students for goal attainment.

The administrative process of any organization centre on leadership approaches put forward by the administrator to motivate employees for maximum performance. Otherwise low productivity would result as seen by Hogan (1990) who investigated three types of flawed leadership and found that some principals still exhibit flawed behaviours despite high interpersonal relationships in schools which result in negative work performance of teachers. The study conducted by Mitchell and Tucker (1992) pointed out, that transformational leadership will be seen as only one part of a balanced approach to creating high performance in school for both teachers and students.

The study by Ekpoh (2003) on Reward system, physical working environment and secondary school teachers' work performance reveals that teachers are usually paid last after all other public servants have been paid. This situation leads to poor work output and general loss of interest in teaching job.

Study by Ofoegbu (2001) concluded that no matter how energetic, enthusiastic and committed a teacher may be his level of performance may not produce the required result in teaching because his/her action to satisfy motive is affected by negative context of the work environment i.e. limited work motivation.

Among, reasons for teacher low performance; Okoro (1998) observes that in spite of the roles teachers play in the education system, teachers were neglected in terms of support and welfare. Teachers were isolated from all other workforce in terms of recognition, respect or recommendation for political post and 
welfare packages. So, when teachers are not treated fairly, they may not motivate the students to learn in order to improve quality of our secondary students' performance.

Submission of Obi (1990) reveals that teachers effective performance and job satisfaction is a function of the following;

- Principal leadership styles \& supervision

- Availability of teaching and learning materials

- Knowledge of the subject matter

- Teacher student ratio and

- Knowledge of the student among others.

By this, a teacher has to create an atmosphere, which is conducive to learning; when he/she is adequately motivated to do so. In other words, effort must be made to provide opportunity for the active and continuous participation of each child in any aspect of the learning situation.

Sergiovanni (1990) found that teachers obtain their greatest satisfaction/motivation through a sense of achievement in reaching and affecting students; experiencing recognition, and feeling responsible. More on the findings of this study had it that majority of school administrators and teachers cited three policies that effectively improve morale and motivated them; staff shared governance, in - service education and systematic education.

Study of Akpan (2001) on motivating teachers for effective job performance; a note to school administrators concluded that teachers attach more premiums on favourable conditions of their work environment as factor for increase work performance.

Lack of consideration about motivation of teachers by school managers made them to be less committed to school work. Teachers often than not are de-motivated by the negative context of their job such as lack of recognition for work well done which cause non-commitment to school work. Lack of regular payment of teachers' salaries and allowances, result in teachers abandoning classrooms for other greener pastures. It is based on these that this study intended to find out how motivational strategies can enhance teaching performance in schools.

The following null hypothesis was formulated and tested in this study. There is no significant influence of motivational variables on teachers' teaching performance.

METHOD: The research design adopted was expost-facto research design because the major variables of this study- Motivational strategies and teachers' teaching performance were already in existence.

A simple random sampling technique was used to select 360 teachers, 20 teachers were selected from each of the 18 public secondary schools in the study area.

Data for the study was collected using researcher-made questionnaire titled: "Principal's motivational strategies for teachers teaching performance (PMSTTP)". The questionnaire was divided into 2 sections, $A$ and $B$. Section A sought demographic data such as name of school, sex, types of school, principals' sex, years of teaching experience and teaching subject. Section B sought to elicit information from teachers on their principal motivational strategies. Section $B(1)$ elicited information from them on their teaching performance. It was a four-point Likert type questionnaire ranging from Strongly Agree, Agree, Disagree and Strongly Disagree. The reliability for the instrument was determined through the split-half method test which ranged from 0.58 to 0.74 . Since the reliability of the instrument was ascertained, data obtained were analyzed using one-way analysis of variance (ANOVA). The population for the study comprised all the teachers in all the 18 public secondary schools in Uyo-Urban, Akwa Ibom State. The research area covered UyoUrban, Akwa Ibom State.

The motivational variables covered in the study included:

- praise and commendation

- in-service training

- regular salary payment

- regular promotion; and

- provision of teaching facilities

\section{RESULTS}

In order to determine the influence of motivational strategies adopted by the principal on teachers' teaching performance, a one-way analysis of variance (ANOVA) was carried out. The teachers were sorted into 3 groups depending on the perception of their principal's level of motivation. Then, the mean and standard deviation of groups were calculated. 
Table 1

One-way ANOVA Summary of Influence of Motivational Variables on Teacher's Teaching Performance

Level of motivation

Low
Moderate
High
Total
Source of Variation
Between Groups
Within Groups
Total

$P<.05, d f=2,357$, Critical F-value $=3.00$

From table 1 , the calculated F-value of 21,529 exceeds the critical F-value of 3.00 for 2,357 degrees of freedom at 0.05 level of significance. This implies that, there was significant influence of principal's application of motivational variables on teachers teaching performance. And this led to the rejection of the null hypothesis and research hypothesis retained. The result also implies that teachers in a group who had high perception of their principal's application of motivational variables in the day-to-day administration of the schools showed high performance on their teaching job. In effect, this result made us to understand that principals who motivated their teachers highly using the motivational variables as:

- praise and commendation

- regular salary payment

- regular promotion/in-service training

- provision of teaching facilities would certainly enjoy high teaching performance from the teachers.

\section{DISCUSSION OF RESULT}

The result of the study revealed a significant positive influence of motivational variables on teachers' teaching performance. The implication of this findings means that principals who apply the motivational strategies to motivate their teachers highly, would in turn enjoy high teaching performance among teachers. On the other hand, principals who do not motivate teachers by being rude, criticizing teachers before students, delay in the payment of salaries and other entitlements, pose a threat to their maximum teaching performance. Indeed, the stress caused by poor financial motivation of teachers, poor teaching facilities and irregular promotion/in-service training conflicted with teachers classroom activities.

Similar result obtain by previous researchers like Ukpong (2003), Emanghe (1998), Ekpoh (2003) also confirmed significant influence of motivational variables on employees' work performance. For instance, when teachers do well in their teaching task and other extracurricular activities such as games and sports, science quiz; such teachers should be commended in order to energise and motivate them for maximum performance in school task in future. Such praise and commendation would also be a source of encouragement to other teachers to take more challenging task in order to win more praise and commendation for themselves also.

The reason for the said outcome of this study pointed to what Obi (1990) concluded, that in-service training helps the teachers to become more proficient in discharging their duties. This is because teachers who are encouraged to participate in training programmes, seminars, conferences and workshops would be kept abreast with current professional information that will help them to perform better in their teaching job.

The significant influence of motivational variables on teachers teaching performance remains paramount as Ofoegbu (2001), Akpan (2001), concludes that high internal motivation by school administrators have shown that teachers are motivated more by intrinsic than extrinsic 
rewards. That is, administrators of schools, should always find good things to say about teachers, as well as publicly recognizing the work of staff and students who have contributed to school improvement. For instance, principals should write private notes to teachers expressing appreciation for special efforts i.e., recognize work done well by teachers to boost their ego.

Nevertheless, the outcome of this study was inconsistent with the studies of Sergiovanni (1990), Hogan (1990), Okoro (1998), Ndu (1998), Ozigi (1992), which showed that in spite of the roles teachers play in the education system, there is abundant evidence suggesting that teachers are neglected in terms of motivation, and this affect their work performance and maximum productivity in the education system. The reason for the variance, however, pointed to the fact that though they were operating from different settings, their studies showed negative performance as a result of demotivation. For instance, the consequence of non-availability of teaching facilities and resources is that, no matter how committed a teacher might be, his level of performance might not provide the required result in teaching because of negative context of the work environment, (i.e. inadequate teaching facilities).

More so, hardly are teachers all over Nigeria in general and in the study area in particular sponsored for conferences or for further training in a way of motivating them for greater performance. Teachers are indispensable human resources in the education industry, but ironically, teachers' motivation is grossly inadequate in the areas of salary and allowances.

\section{CONCLUSION}

The conclusion drawn in this study is that motivational variables such as praise and commendation, regular pay, regular promotion/inservice training and provision of teaching facilities have significant influence on teachers teaching performance. Principals of schools should apply these motivational strategies in the day-to-day administration of schools so that teachers would show high commitment to teaching.

\section{RECOMMENDATIONS}

Based on the findings, the following recommendations were made:

1. That principals should recognize work done well by teachers to boost their ego to enhance their work performance;

2. That teachers should be highly praised and commended for maximum performance;

3. Ministry of Education should make it a policy to provide all public secondary schools in the study area with necessary facilities to facilitate effective teaching and learning in schools.

\section{REFERENCES}

Akpan, C. P., 2001. Motivating teachers for effective job performance. A note for school administrators. West African Journal of research and development in Education, 8 (1), 195-205.

Amadi, A., 1987. Effect of principals leadership behaviour on teachers' level of commitment, conformity, co-operation and participation in school organization. Unpublished M. Ed Thesis. University of Calabar, Calabar, Nigeria.

Ekpoh, U. I., 2003. Reward system physical working environment and secondary school teachers work performance. Unpublished M.Ed Thesis, University of Calabar, Calabar-Nigeria.

Ellis, T. I., 1984. Educational management. Eric Digest, 6(11), $190-196$.

Emanghe, G. A., 1998. Application of Mary Parker Follets theory of human relations on staff management efficiency in secondary schools in Cross River State. Unpublished M.Ed Thesis, University of Calabar, Calabar.

FGN, 2004. National Policy on Education (2004). $4^{\text {th }}$ ed. Lagos, Federal Ministry of Education. 
Hogan, R., 1990. The dark side of charisma, measures of leadership. New Jersey: Leadership library press.

Leah, A \& Kirk - Patrick, S., 1990. A classroom perspective on students mobility Elementary school journal. 91 (2), 90 95.

Mitchell, D. E. and Tucker S., 1992. Leadership as a way of thinking. S Educational Leadership, 3(49), 5 - 9.

Ndu, A. N., 1998. "Renovation and Renewal of Education" in private and community participation in Nigeria: The Nigerian Academy of Education.20 (3), 28 - 30.

Obi, E., 1990. "Towards teacher effectiveness in Nigerian schools: A case study of Anambra State". Journal of General Studies, 1, 86.

Ofoegbu, F. I., 2001. Motivational factors and the achievement of classrooms effectiveness in Edo State secondary schools. In current issues in Educational Management in Nigeria. In Nwagwu, N.
A., Ehiametalor, Ogunu \& Mon Nwadiani eds. Publication of the Nigerian Association for Educational Administration and Planning.

Okoro, D. C. U., 1998. "Building and sustaining teacher morale and job satisfaction". Teachers and Teaching in Nigeria. The Nsigerian Academy of education. Year Book, No. 2, P. 89.

Ozigi, A., 1992. Keynote address for the National conference on financing teacher education at A.I.C.E, Owerri, $6^{\text {th }}-11^{\text {th }}$ December.

Pastor S. R. and Erlandson A. D., 1982. What motivates teachers? Motivating teachers for excellence. Eric digest, 6(11), $20-30$

Sergiovanni, T. J., 1990. Adding value to leadership and getting extraordinary result. Educational Leadership, 3 (47), 812.

Ukpong, N. N., 2003. Human relations factors of secondary school administrators and teachers' attitude to work in Uyo Urban, Akwa Ibom State. Unpublished M. Ed. Thesis, University of Calabar, Calabar, Nigeria. 